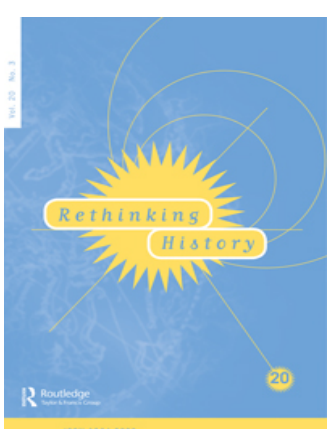

Rethinking History

The Journal of Theory and Practice

\title{
Engaging the past: mass culture and the production of historical knowledge
}

\section{João Rodolfo Munhoz Ohara}

To cite this article: João Rodolfo Munhoz Ohara (2016) Engaging the past: mass culture and the production of historical knowledge, Rethinking History, 20:3, 486-488, DOI:

10.1080/13642529.2016.1114756

To link to this article: https://doi.org/10.1080/13642529.2016.1114756

$$
\text { 曲 Published online: } 26 \text { Jan } 2016 .
$$

$\sqrt{6}$ Submit your article to this journal ๘

Џلll Article views: 180

View Crossmark data ¿ 
is, rather, a wish to avoid what one might call a bout of sterile theoreticism, a confirmation bias that points out historians acted professionally and, shucks, here are a quite a few examples of that. Professionalism is so loose an idea in this book that it really loses any saliency as a conditioning force; the notion does not add, to turn to Torstendahl's optimum norms, anything to the epistemological practices of history. While Rise and Propagation makes a point, a soft realist case for the history of history, it does not go on to show the sheer vivacity presumably present in the formation of the historical profession.

\section{References}

Evans, R. J. 2001. In Defence of History. London: Granta.

Jamie Melrose

University of Bristol

@ Jamie.Melrose@bristol.ac.uk

(c) 2016 Jamie Melrose

http://dx.doi.org/10.1080/13642529.2016.1103043

\section{Engaging the past: mass culture and the production of historical knowledge, by Alison Landsberg, New York, Columbia University Press, 2015, xi + 213 pp., £20.50 (paperback), ISBN 978-0-231-16575-4; £62 (hardcover), ISBN 978-0-231-16574-7}

In her new book Alison Landsberg presents a compelling case for studying mass-media's engagements with history without either falling for an empty 'methodological populism' or patronizing mass-media consumers. Her work provides us with valuable insights into how narratives which are mainly considered 'entertainment' are able to produce historical knowledge, even if such knowledge is different from what is produced by academic books. Furthermore, her book introduces a notion of consumption which clearly shows the limits of the many works that portray consumers as passive receivers of standardized content, or as unable to appreciate 'good art'. In sum, this book is to be recommended to those who are interested in how historical narratives might look in forms of media other than the historical monograph, but also to those who want to think about our contemporary relations to the past more broadly.

In terms of presentation, 'Engaging the Past' has a fairly standard monographic structure, with an introduction mostly focused on theoretical issues, four chapters devoted to case studies, and a conclusion. Landsberg's theoretical reflections are especially interesting: She uses Collingwood's category of 'historical thinking' as a reference point in relation to which she assesses the potential each case holds for fostering historical knowledge (4-11). This category is 
based on the idea that the historian must strive to re-enact the past in his/her own mind in order to understand it. But re-enactment is not sufficient. The historian must subsequently distance him/herself from this re-enactment and critically reflect on it. As Landsberg says, 'Historical knowledge requires more than immediate consciousness; there must be a self-reflexive component, a reflecting on the process of re-enacting the experience' (5). From there, she argues that mass media can serve as an alternative means to convey historical narratives, and that such narratives do not necessarily need to be considered as 'distortions' of the past, ideologically constructed narratives, or 'mere' entertainment. Her thesis is that historical films or TV shows can produce historical knowledge, even if this may not be the case for the most part of mainstream media. But for that to happen, so Landsberg argues, these narratives must employ strategies to disturb any easy relationship of identification between viewers and characters, and thus induce a self-consciousness and distancing of the type that Collingwood had in mind.

The author is quick to point out that the case studies she has chosen for analysis were chosen precisely because they use specific material that is not easy to identify with and makes good use of different techniques in order to disturb the viewer's relation to the narrative. She says, 'I use these shows not because they are the only or the best examples of the historically conscious drama, but rather because they make visible a particular audio-visual methodology for the production of historical knowledge [...]' (109). She also acknowledges that a lot of what is produced in mainstream media industry probably does not have the intention of realizing the potential to foster historical knowledge as defined by her model (178). Nevertheless, Landsberg maintains that this pre-selection of cases is not detrimental to her argument because she is not arguing that all historical narratives in mass media produce historical knowledge. Hers is a much more modest claim - that historical narratives in mass media can produce historical knowledge, given certain conditions. In order to accomplish this task she constructs a refined model to understand how mass-media could be used to foster historical consciousness and knowledge.

Her analyses of movies and series can be seen as having much more conceptual clarity - and overall analytical strength - than the rest of the book, though this is perhaps due to the fact that nowadays cinema seems to be much more academically palatable to most historians than digital exhibitions and reality TV shows. Moreover the considerable bibliography available to those studying historical films certainly contributes to such differences in Landsberg's treatment of the sources. Her analyses of the films, 'Milk' and 'Hotel Rwanda', for example, clearly show the power of her argument: the role of archival footage (44-46) and visual and aural interruptions (49-52) in disrupting immersion and identification, and the blurring of lines of demarcation between 'real events' and fictional depiction (39-40,48-49). These formal strategies interrupt what could be a seamless, continuous temporal line, reminding the audience of the 
distance and otherness of that which is being presented to them. And it is this demarcation that enables viewers to think historically about what they are watching.

There was something, however, that puzzled me throughout my reading of the book. While the author talks at length about the potential reactions from spectators, she only works with the narrative products themselves, and not with the way those products are experienced by consumers. Of course her analyses of the narrative strategies employed by TV dramas like 'Mad Men' are well done and are able to support her main thesis - that these different media also have the potential to present material capable of producing historical knowledge. I agree that,

Although $[\ldots]$ one can never predict how any individual will respond to or read a film, it would be equally naive to dismiss the many formal strategies filmmakers deploy in an attempt to position their viewers to understand events in a particular way. (47-48)

Yet, one is left wondering about those spectators in whose minds all historical thought would happen.

In the end, 'Engaging the Past' is a stimulating book to read. It presents interesting theoretical insights, provides a good framework in relation to which we can think about the formal dimension of historical narratives, and successfully tries to answer the questions it sets out to address. Alison Landsberg makes such a good case for her thesis one is left wishing that there were more historical movies and series produced with this kind of historical understanding in mind.

\section{Funding}

This work was supported by the São Paulo Research Foundation [grant number 2014/24913-8].

João Rodolfo Munhoz Ohara History Postgraduate Studies Program, São Paulo State University, Brazil São Paulo Research Foundation Fellow @oharajrm@gmail.com

(c) 2016 João Rodolfo Munhoz Ohara http://dx.doi.org/10.1080/13642529.2016.1114756 